\title{
ウレタン麻酔下マウスの大脳皮質における 緑色自家蛍光と自発脳波の相関関係
}

\author{
片 山統 裕* . 中 $川$ 輝* ${ }^{*}$ 上野 彩 子*,** \\ 辛島 彰 洋*.中尾 光 之*
}

\begin{abstract}
Correlation between Green Autofluorescence and Spontaneous Electroencephalogram in the Cerebral Cortex of Urethane Anesthetized Mice

Norihiro Katayama*, Daiki Nakagawa*, Ayako Ueno*,**, Akihiro Karashima* and Mitsuyuki NAKaO*
\end{abstract}

\begin{abstract}
We investigated the relationship between the green auto-fluorescence (GAF) and the spontaneous electroencephalographic signals (EEG) recorded from the neocortex of mice under urethane anesthesia. Power spectral density analysis showed that both the GAF and the EEG have a significant activity in the delta frequency band $(0.5-1 \mathrm{~Hz})$. Cross-correlation analysis and coherence analysis revealed that the GAF and the EEG were correlated in the delta frequency band. These results suggest that the delta frequency component of GAF would be useful to study the spontaneous activity of the neocortex. Visualization of the spatio-temporal dynamics of the GAF delta activity revealed complex phenomena such as propagation of the localized activity and disappearance of the activity after collision. These data suggest the usability of GAF for investigation of the delta activity.
\end{abstract}

Key Words: flavoprotein, brain, spontaneous activity, propagating wave, delta wave

\section{1.はじめに}

脳の感覚刺激に対する応答特性や，大脳皮質領域間の結 合関係を研究する新しい手法として，ミトコンドリア内の フラビンタンパク質が発生する緑色自家蛍光 (Green AutoFluorescence, GAF) イメージング法が注目を集めている ${ }^{1)}$. 本手法は，マウスなど，薄い頭蓋骨をもつ動物では蛍光変化 を経頭蓋的に観察することが可能であるため, 大脳皮質の活 動を低侵襲かつ高空間分解能で観察できるというメリットが ある。

脳の活動は感覚刺激などによらない自発活動が大きな割合 を占めており, 刺激応答性にも強い影響を与えていることが知 られている2). 脳の自発活動の研究には脳波 (EEG) や機能 的 MRI ${ }^{2)}$ などが用いられてきたが, GAF イメージング法を 用いた報告はない。信号が微弱で信号対雑音比が低く，刺激

* 東北大学大学院情報科学研究科 仙台市青葉区荒巻字青葉 6-3-09

** 日本学術振興会 東京都千代田区麹町 5-3-1

* Graduate School of Information Sciences, Tohoku University, 6-3-09 Aza-Aoba, Aramaki, Aoba-ku, Sendai

** Japan Society for the Promotion of Science, 5-3-1 Kojimachi, Chiyoda-ku, Tokyo

(Received January 31, 2014)

(Revised May 21, 2014)
応答特性を評価する際には多数回の同期加算が必要であるこ と，脳の自発活動との関連がよくわかっていないことなどが 原因として考えられる ${ }^{3)}$. しかし, 先に述べた GAF イメー ジング法の特長を考えると, 脳自発活動の研究に利用できれ ば有用性が大きいと考えられる。

本研究では, 低ノイズ高感度蛍光観察系を用いて, ウレタ ン麻酔下マウスの大脳新皮質において GAF イメージングと 同時に大脳皮質脳波を記録し，時間的・空間的関係を解析す る。これにより, EEGのデルタ波帯域活動と GAF 信号が相 関していることを明らかにする。この性質を利用して, GAF 信号からデルタ波帯域の成分を抽出して時空間的活動を視覚 化し, 高い空間分解能で脳自発活動を解析する手法を提案す る。この手法を実データに適用することによって，大脳皮質 の GAF デルタ波活動の時空間ダイナミクスの性質について 検討する.

\section{2. 実験方法}

\section{1 実験動物}

本研究は東北大学動物実験委員会の承認のもとで行なわれ た. Shibuki らの報告 ${ }^{1)}$ に倣い, マウスの in vivo 経頭蓋 GAF イメージングを行なった。実験には 6 匹の C $57 \mathrm{BL} / 6$ マウス (雄，10〜12 週齢）を用いた。手術および実験はすべてウレ夕 ン麻酔下 $(1.6 \mathrm{~g} / \mathrm{kg})$ で行なった。 キシロカイン局所麻酔した 

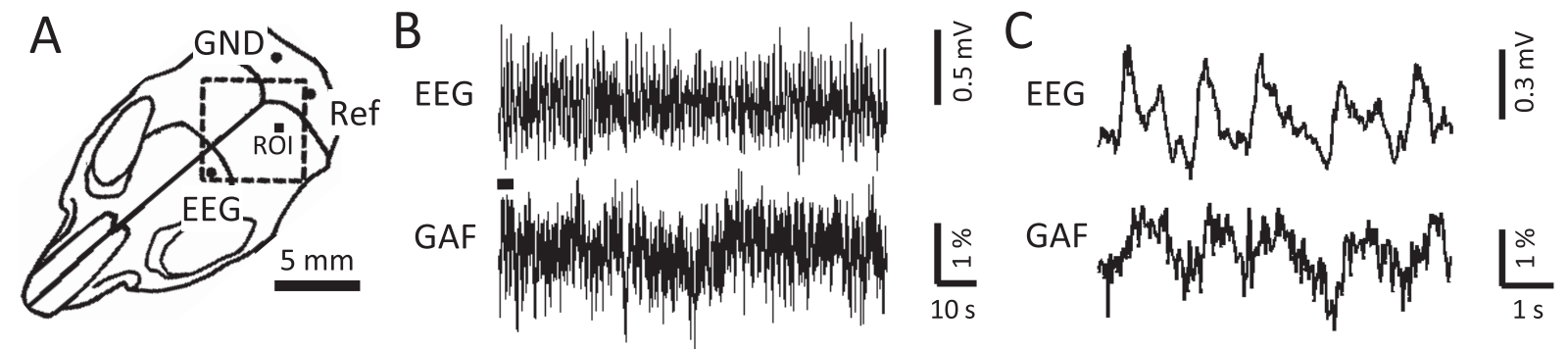

Fig. 1 (A) Layout of the EEG electrodes (dots) and the area of GAF imaging (dashed rectangle). (B) Simultaneously recorded EEG and the GAF signals. The GAF was recorded at ROI. (C) An extended graph indicated by the bar in the Fig. 1(B)

頭皮の一部を切除して頭蓋骨を露出させた後, 右頭蓋骨に頭部 固定用プレートをデンタルセメントで接着した．脳波を記録 するために，頭蓋骨に穿孔しステンレス製ビス電極を設置し た (Fig.1(A), EEG 電極：ブレグマを基準に吻側 $1 \mathrm{~mm}$, 左 外側 $1.5 \mathrm{~mm}$, 参照電極 (Ref) およびグランド電極 (GND)： ラムダから尾側 $2 \mathrm{~mm}$, 外側にそれぞれ左右 $2 \mathrm{~mm}$ ). 観察領 域とその周辺の頭蓋骨に生理食塩水を塗布し, 頭蓋骨が透明 になるまで放置した，その上に流動パラフィンを塗り乾燥か ら保護した．実験中は必要に応じてウレタン $0.2 \mathrm{~g} / \mathrm{kg}$ を腹腔 注射し，麻酔レベルを維持した。

\section{2 緑色自家蛍光イメージングおよび脳波記録}

麻酔下のマウスをアクリル製簡易ステージの上に保持し, 観察領域が顕微鏡の対物レンズ（オリンパス, BX50WI, XLFluor4x/340）と平行になるように設置した。顕微鏡に 設置した冷却 EM-CCD カメラ（浜松ホトニクス, C9100-13) で GAF イメージを取得した（励起 460〜 490 nm, 蛍光 > $515 \mathrm{~nm}, 128 \times 128$ 画素, $16 \mathrm{bit).フレームレートは} 35.8 \mathrm{~ms}$ とした。視野はおよそ $6 \mathrm{~mm}$ 四方であった。画像収録ソフト ウェアはAquacosmos（浜松ホトニクス）を用いた.

EEG 電極で導出した信号は脳波記録用アンプ（日本光電， JH-440J, JB-440J, AB-610J および MEG-6108) で増幅・ 帯域制限したのち $(0.5 \mathrm{mV} / \mathrm{V}, 0.08 \sim 300 \mathrm{~Hz}$, 高域通過およ び低域通過フィルタのいずれも 1 次アナログフィルタ), サン プリング周波数 $1 \mathrm{kHz}$ で A/D 変換した (Axon Instruments, Digidata 1322A, 16 bit). GAF イメージと同期をとるため のタイミング信号も EEG と同時に記録した。

\section{3 データ解析}

デー夕解析には MATLAB (Mathworks Inc.) を使用した. GAF イメージは，まず， $32 \times 32$ 画素にビニングしてから， 各ビンに対して退色によるドリフトを最小二乗法により直線 近似して除去した。その後, EEG と同時記録したタイミング 信号を参照して GAF イメージと脳波の時間合わせを行なっ た。その後, EEG をディジタルフィルタによりカットオフ $40 \mathrm{~Hz}$ でアンチエイリアシング処理した。この処理には空関 数法により設計した有限インパルス応答フィルタ（次数 100) を用いた，GAF はフレーム間を線形補間した。最後に EEG と GAF 信号を周波数 $100 \mathrm{~Hz}$ で同じタイミングでリサンプ
リングした。

これらの信号に対し，パワースペクトル密度，相互相関関 数, および振幅 2 乗コヒーレンス $C_{x y}(f)$ を計算した。相互 相関関数は $\mathrm{EEG}$ を時間基準においた. 振幅 2 乗コヒーレン ス $C_{x y}(f)$ は, 同時記録された 2 つの信号 $x$ および $y$ （たと えば EEG と GAF）の周波数 $f$ に扔ける相関係数の 2 乗の 意味をもつ統計量 ${ }^{4)}$ であり, 次式で定義される.

$$
C_{x y}(f)=\frac{\left|P_{x y}(f)\right|^{2}}{P_{x x}(f) P_{y y}(f)}
$$

ここに, $P_{x x}(f)$ および $P_{y y}(f)$ はそれぞれ $x$ および $y$ のパ ワースペクトル密度を, $P_{x y}(f)$ は $x$ と $y$ のクロスパワース ペクトル密度を表わす。パワースペクトル密度解析には高速 フーリエ変換を用いた。時間空のサイズは 45000 点とし，空 関数には矩形空を用いた。

\section{3. 結果と考察}

\section{1 脳波と緑色自家蛍光の相関関係}

ウレタン麻酔下のマウスから記録された大脳皮質脳波 (EEG) と緑色自家蛍光 (GAF, 観察位置は Fig. 1(A) の Region of Interest, ROI) の波形を Fig. 1(B) および Fig. 1(C) に示す. またそのパワースペクトル密度を Fig. 2(A) および Fig. 2(B) に示す.

過去の報告 ${ }^{5)}$ と同様に, ウレタン麻酔下の大脳皮質 EEG か らはデル夕波と呼ばれる $1 \mathrm{~Hz}$ 程度の振動的活動が顕著に観察 された (Fig. 2(A) の黒䅡)。マウスによっては, デル夕波 が弱くなる時間帯に $2 \sim 3 \mathrm{~Hz}$ の振動的活動が観察されること があった (Fig. 2(A) の白矢頭)。これはウレタン麻酔によっ て低周波化したシー夕波であると考えられる ${ }^{5)}$. また，マウ スによっては，200 秒程度の周期でデル夕波の振幅が変動す る現象も観察された (Fig. 3(A))。これはデル夕波とシー夕 波が交代的に表われる現象に対応する ${ }^{5)}$.

GAF は EEG に比べ低周波のゆらぎ成分が大きかった (Fig. 1(B), Fig. 3(B)). 観察する時間帯によっては EEGの デルタ波と同期した周期現象が明瞭に認められた (Fig. 1(C)). パワースペクトル密度においても, デル夕波帯域に明瞭なピー クが確認された (Fig. 2(B) の黒矢頭)。これらの現象は実験し たすべてのマウスにおいて観察された。しかし，EEGのシー 


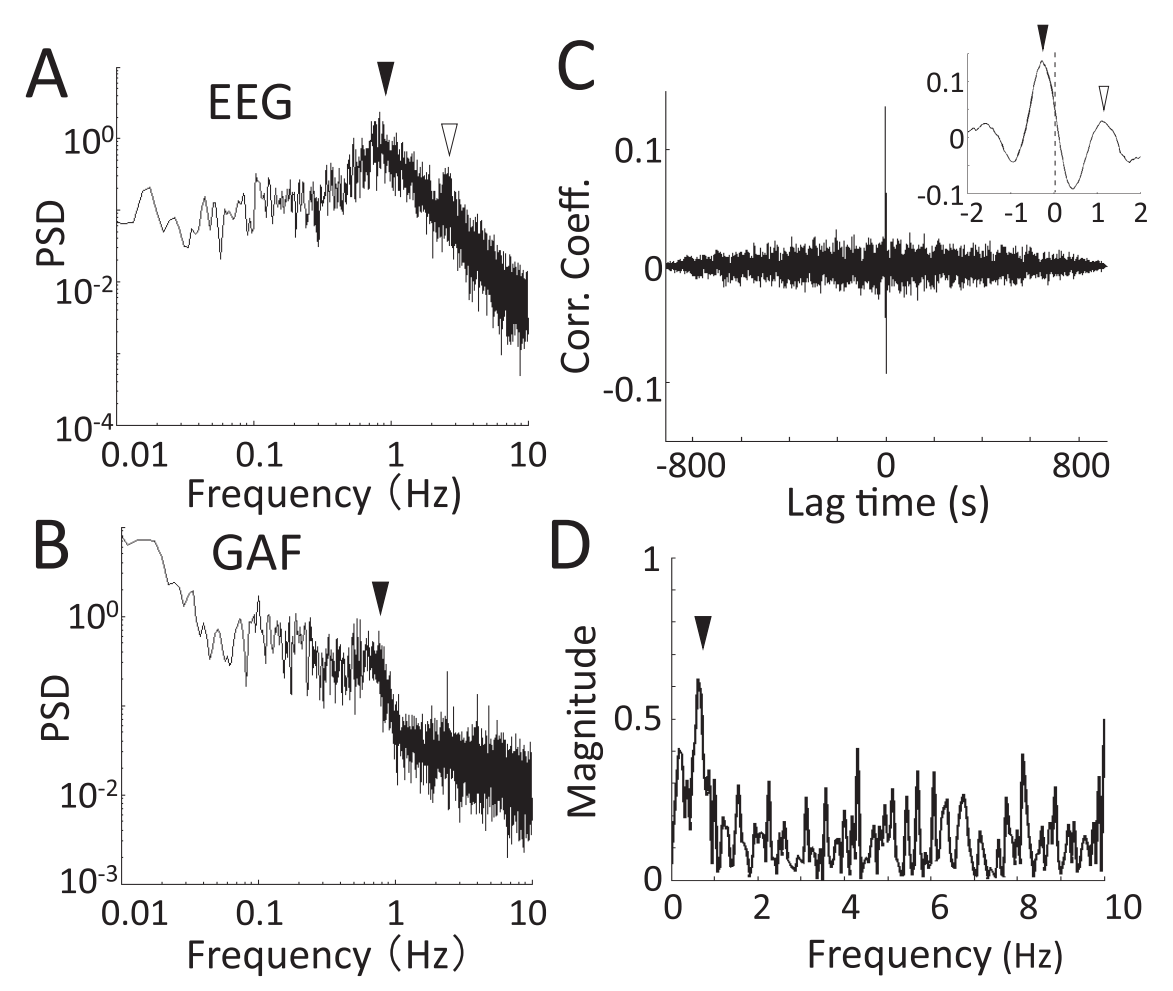

Fig. 2 (A) Power spectral density of the neocortical EEG signal. (B) Power spectral density of the neocortical GAF. (C) Cross correlation function of the EEG and the GAF. Inset is an extended graph near lag time $=0$. (D) Magnitude-squared coherence function of the EEG and the GAF

夕波と同期した成分については確認することができなかった。

EEG を基準信号として GAF との相互相関関数を計算し たところ，ラグ時間 0 秒周辺に明瞭なピークが認められた (Fig. 2(C) の黒矢頭，相関係数 $0.16 \pm 0.059, N=6)$. ま た, 相関関数は 1.5 秒程度の周期で減衰振動を呈していること から (Fig. 2(C) の黒および白矢頭), EEG と GAF において デル夕波帯域の活動が同期的であることが示唆される. EEG と GAF の振幅 2 乗コヒーレンス関数を計算した。 その結果, デル夕波帯域成分の振幅 2 乗コヒーレンスが強いことが示唆 された (Fig. 2(D) の黒矢頭).この性質も，実験したすべて の動物で観察された (Fig. 4).

つぎに, EEG と GAF の瞬時的な関係を見るために,バンド パスフィルタを用いて各信号をデル夕波帯域 $(0.08 \sim 1.2 \mathrm{~Hz})$, デル夕波より低周波帯域（<0.08 Hz）拈よびデル夕波より 高周波帯域 $(>1.2 \mathrm{~Hz})$ の 3 つの帯域に分割し, 波形を比較 した（Fig. 3). 図に示されているように，デル夕波帯域の成 分に関しては, EEG と GAF の波形がよく一致しているこ とが確認された。帯域ごとに EEG と GAF の相互相関関数 を計算した結果, デルタ帯域の相関係数が $0.46 \pm 0.11$ (平均 \pm 標準誤差, $N=6$, 以下同様) であったのに対し，低周波 域は $0.16 \pm 0.04(N=6)$, および高周波域は $0.07 \pm 0.027$ $(N=6)$ であった.

EEG の低周波および高周波の成分はいずれも振幅の包絡 線がデル夕波帯域の成分と類似した時間経過を示した。低周 波成分についてはデル夕波に関連した脳波のベースラインの
変動に，また高周波成分はデル夕波の up-state に活動する ニューロンの活動電位に由来するものと考えられる ${ }^{6)}$.

GAF の低周波成分は, デル夕波帯域の活動に伴って緩やか に増加し, デルタ活動が停止すると急速に減少するパターン が観察された。変動パターンが EEG と異なることから，たと えば脳血流変化など異質な情報を表現している可能性が考え られる。GAF の高周波成分は白色ノイズ様で, EEGのシー 夕波帯域活動などとの関連を確認することはできなかった。

以上の結果から，バンドパスフィルタを用いて GAF から デル夕波帯域成分を抽出することにより, EEGのデル夕波 活動を推定できることが示唆された。皮質デル夕波活動は, 錐体ニューロンの膜電位レベルが比較的高い up-state と低い down-state が交互に周期的に表われる現象と相関しているこ とが知られている7)。up-state 中には回帰的シナプス入力が 活性化し，また down-state 中には up-state 中にバースト発 火したニューロンが after-hyperpolarization する。これらの 活動によって生じる皮質内の電流シンクおよびソースが電流 ループを作り，その一部が皮質表面を流れることで生じる電 圧変化がデル夕波 EEGであると考えられている ${ }^{8)}$.

一方，大脳皮質 GAF は主にミトコンドリア内の代謝活動 で増加する酸化型フラビンタンパクによる. 脳内のミトコン ドリアはニューロンの樹状突起やシナプス終末部に高密度に 分布している ${ }^{9)}$. GAF がシナプス伝達の活性を強く反映し ていることを示唆する報告もあり ${ }^{10)}$ ，これにより EEGのデ ル夕波と GAF の相関関係を説明できる可能性がある. 
A

EEG

Full band

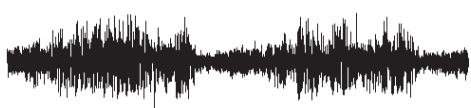

DC-0.08 Hz whanhamonn

$0.08-1.2 \mathrm{~Hz}$

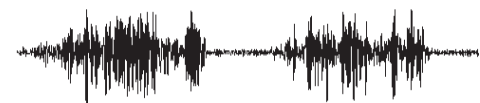

$>1.2 \mathrm{~Hz}$

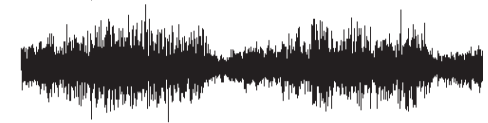

B

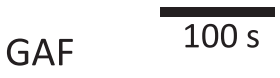

Full band

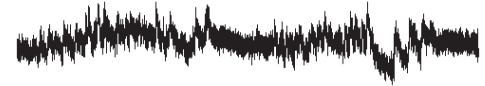

DC-0.08 Hz

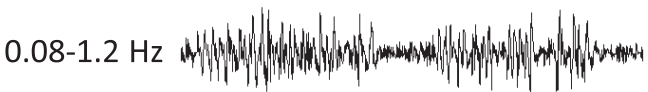

$>1.2 \mathrm{~Hz}$

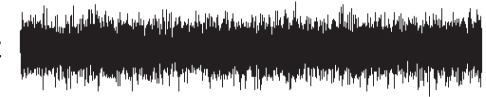

Fig. 3 (A) Full band and band-divided EEG signal. (B) Full band and band-divided GAF signal. Amplitude of each signal was normalized for comparison of the waveform

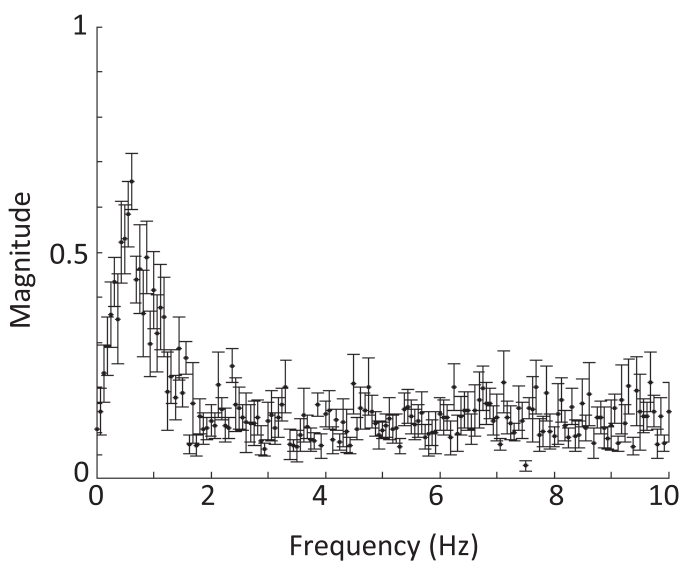

Fig. 4 Magnitude-squared coherence function of EEG and GAF signals of mice $(N=6$, mean \pm SEM $)$

\section{2 緑色自家蛍光の空間分布}

EEG と GAF の相関の空間構造を調べるために, GAF の 各画素と EEG との相互相関関数を計算した. Fig. 5(A)に 相関関数の最大值 (最大相関係数) の空間分布を示す。これよ り大脳皮質の広い範囲で GAF が EEG と相関していること， および相関係数が電極と画素との距離にあまり依存してない
Full frequency band
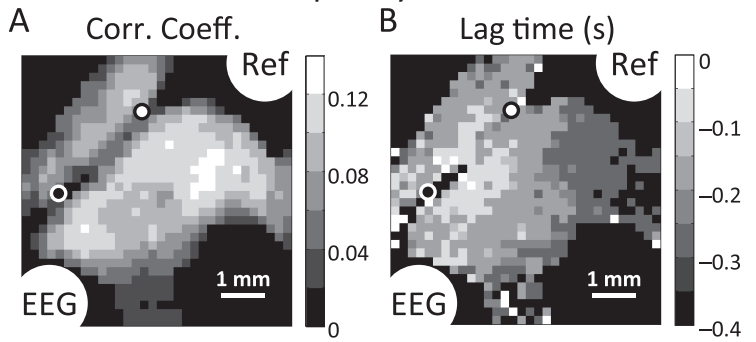

Delta frequency band $(0.08-1.2 \mathrm{~Hz})$
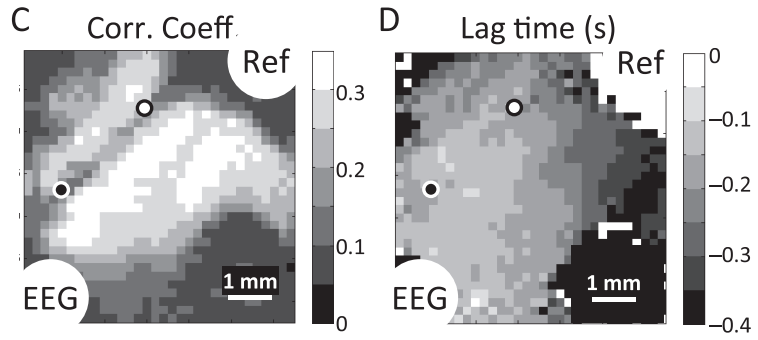

Fig. 5 Improvement of cross-correlation between EEG and GAF by the delta-band-pass filtering. (A and C) Spatial distribution of the maximal cross-correlation coefficient of EEG and GAF. (B and D) Spatial distribution of lag time. Filled circle and open circle respectively indicate the bregma and the lambda of the skull

ことがわかる。この図の場合，左脳中央部の頭頂から側頭に かけてやや相関係数が小さい領域が観察される。この領域に は比較的太い血管が大脳皮質の表面に分布していた。これが 光を散乱するなどの影響により信号対雑音比が悪化し，相関係 数が低下したのだと考えられる. EEG および GAF のデル夕 波成分を抽出して同様の解析を行なったところ (Fig. 5(C)), 空間分布に大きな変化は見られなかったが，相関係数の值が $2 \sim 3$ 倍程度大きくなり，SN 比が改善された。

つぎに相関係数を最大にするラグ時間の空間分布を調べた (Fig. 5(B))。 その結果，ラグ時間が大脳皮質の頭頂内側部か ら側頭葉および後頭葉に向かって単調に減少する傾向がみら れた. EEG および GAF からデル夕波を抽出した場合もこの 傾向に変化は見られなかった（Fig. 5(D)).

本実験では，EEG 電極と参照電極をかなり離れた位置に設 置したため, EEG 信号は脑の大域的活動平均を捉えているも のと考えられる。一方，GAF は局所的代謝活動を反映して いると考えられるため，相関係数には空間依存性が現われな かった可能性が考えられる。一方，ラグ時間は前頭内側部か ら後頭にかけて単調な変化がみられたことから，大脳新皮質 において局所的活動が大脳皮質頭頂部から側頭葉へ向かって 伝播する現象が生じている可能性が示唆される.

\section{3 緑色自家蛍光デルタ波帯域成分の時空間活動}

GAF の各画素の時系列にバンドパスフィルタを適用して デル夕波成分を抽出して構成したイメージの時間変化を調 査した。観察された典型的な活動パターンを Fig. 6 に示す. Fig. 6(A) は後頭葉で観察された孤立局在波様の活動で，この 

A $\frac{0 \mathrm{~s}}{\mathrm{y}} \mathrm{xyy}$
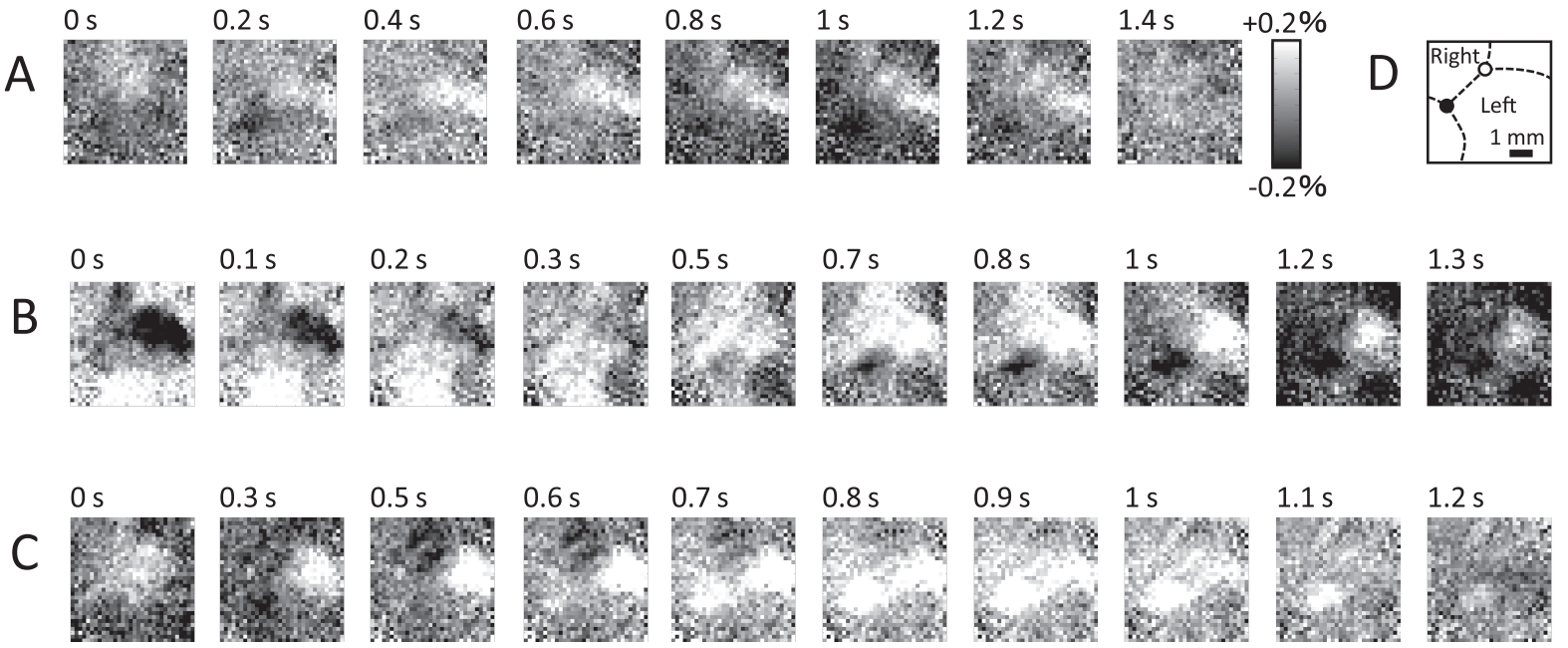

Fig. 6 Examples of spatio-temporal dynamics of the delta-band activity of GAF. (A) A localized transient activity. (B) Initiation, propagation and disappearance of a localized activity. (C) Disappearance of two propagating localized activities after collision. (D) Schematic drawing of the epicranial suture of the skull in the microscopic field. Filled circle and open circle respectively indicate the bregma and the lambda of the skull

場合, $500 \mathrm{~ms}$ 程度で自然に消滅した。最も頻繁に観察された のは興奮波伝播と類似した現象である。その一例を Fig. 6(B) に示す。この例では，頭頂周辺で発生した活動が発達しなが ら頭蓋骨矢状縫合線に沿って尾側に向かって伝播し，後頭葉 に至ると，今度は側頭葉に向かって広がり消滅した。このよ うな現象は Fig. 5(B) および Fig. 5(D) に示した EEG-GAF 相関関数の遅延時間の空間分布に深く関係しているものと推 察される．また非常にまれではあるが，大脳皮質の 2 か所で ほぼ同時に発生した興奮波が衝突して消滅する現象も観察さ れた (Fig. 6(C))。これらの現象は, 神経軸索 ${ }^{11)}$ やべロウソ フ・ジャボチンスキー反応などの反応拡散系で観察される興 奮波伝播と類似している ${ }^{12)}$ 。このことから，大脳皮質のデル 夕波活動の背景にも類似したメカニズムが潜んでいる可能性 が示唆される。

マウスの大脳皮質における興奮伝播現象は, 膜電位感受性

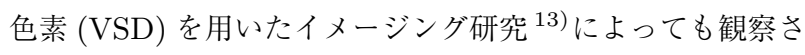
れている.たとえば, Fig. 6(B) に示した興奮の伝播は興奮波 の開始位置や伝播経路など類似点も多く, 同様の現象を観察 している可能性が高い.

VSD は GAF に比べ反応速度が速いため，より高速な現象 を捕捉可能である ${ }^{13)}$. しかし VSD 染色による細胞毒性や観 察領域の頭蓋骨を取り除く手術が必要であるなどの高い侵襲 性があり, 脳の自発活動に重大な影響を及ぼしている可能性 を否定できない. そのため, さまざまな問題はあるものの, 侵 襲性が低いGAF イメージング法には脳の自発活動の研究に おいて一定の有用性があると考えられる.

\section{4. 結 論}

本研究では, ウレタン麻酔下のマウスの大脳新皮質におい
て, 自発 EEG と GAF を同時記録し, 相互相関解析を行なっ た。その結果, 自発 EEG と GAF に相関関係があることが 明らかになった。さらに, コヒーレンス解析などにより GAF が脳のデル夕波活動を反映している可能性が示唆された.

また, GAF のデルタ波活動を抽出して可視化することによ り, 孤立興奮波の発生・伝播・衝突による消滅などの現象が 観察された。これより, 大脳皮質のデル夕帯域活動の背景に は反応拡散系のメカニズムが潜んでいる可能性が示唆された.

これまで GAF は脳の自発活動の研究にはほとんど用いら れてこなかったが, 本研究により, その利用可能性と有用性 が示された。しかし現時点では EEGと GAF の相関関係を 見ているにすぎないので，今後は両者の因果関係を明らかに していく必要がある。また, GAF 信号には血流や脳組織の 散乱なども影響することから，それらの影響について評価す ることも今後の重要な課題として挙げられる.

謝辞 本研究の一部は文部科学省科学研究費補助金『包括 型脳科学研究推進支援ネットワーク』の補助を受けて実施さ れた。

\section{参 考 文 献}

1) K. Shibuki, R. Hishida, M. Tohmi, K. Takahashi, H. Kitaura and Y. Kubota: Flavoprotein fluorescence imaging of experience-dependent cortical plasticity in rodents, 2nd ed., R.D. Frostig (Ed.), In vivo optical imaging of brain function, CRC Press (2009)

2) M.D. Fox and M.E. Raichle: Spontaneous fluctuations in brain activity observed with functional magnetic resonance imaging, Nat. Rev. Neurosci., 8-9, 700/711 (2007)

3）根本, 佐藤：光計測法を用いた脳機能画像表示, 小川, 上野 (監), 非侵襲・可視化技術ハンドブック一ナノ・バイオ・医療か ら情報システムまで—, 304/316, エヌ・ティー・エス (2007)

4）尾崎, 北川 (編): 時系列解析の方法, 朝倉 (1998)

5) T. Wolansky, E.A. Clement, S.R. Peters, M.A. Palczak 
and C.T. Dickson: Hippocampal slow oscillation: A novel EEG state and its coordination with ongoing neocortical activity, J. Neurosci., 26-23, 6213/6229 (2006)

6) M. Bazhenov, I. Timofeev, M. Steriade and T.J. Sejnowski: Model of thalamocortical slow-wave sleep oscillations and transitions to activated states, J. Neurosci., 22-19, 8691/8704 (2002)

7) B. Haider, A. Duque, A.R. Hasenstaub and D.A. McCormick: Neocortical network activity in vivo is generated through a dynamic balance of excitation and inhibition, J. Neurosci., 26-17, 4535/4545 (2006)

8) G. Buzsáki, C.A. Anastassiou and C. Koch: The origin of extracellular fields and currents: EEG, ECoG, LFP and spikes, Nat. Rev. Neurosci., 13-6, 407/420 (2012)

9) T.R. Husson and N.P. Issa: Functional imaging with mitochondrial flavoprotein auto-fluorescence: Theory, practice, and applications, R.D. Frostig (Ed.), In Vivo Optical Imaging of Brain Function, 2nd ed., CRC Press (2009)

10) C.W. Shuttleworth: Use of $\mathrm{NAD}(\mathrm{P}) \mathrm{H}$ and flavoprotein autofluorescence transients to probe neuron and astrocyte responses to synaptic activation, Neurochem. Int., 56-3, $379 / 386(2010)$

11）松本 元：神経興奮の現象と実体 (上), 丸善 (1981)

12) G. Nicolis and I. Prigogine: Self-organization in nonequilibrium systems, John Wiley \& Sons (1977)

13) M.H. Mohajerani, D.A. McVea, M. Fingas and T.H. Murphy: Mirrored bilateral slow-wave cortical activity within local circuits revealed by fast bihemispheric voltagesensitive dye imaging in anesthetized and awake mice, J. Neurosci., 30-10, 3745/3751 (2010)

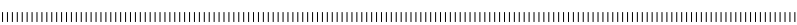

$$
\text { [著 者 紹 介] }
$$

\section{片 山 統 裕 (正会員)}

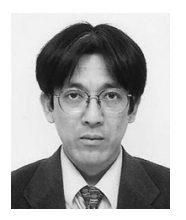

1991 年東北大学工学部卒業, 93 96 年日本学 術振興会特別研究員 (DC). 96 年同大学大学院情 報科学研究科博士課程修了. 博士 (情報科学). 同 年より同大学大学院情報科学研究科助手, 2003 年 同助教授, 2007 年同准教授, 現在に至る. 神経生 理学，神経工学，バーチャルリアリティなどの研 究に従事. 日本生体医工学会, 日本バーチャルリ アリテイ学会, 日本神経科学学会, IEEE, 北米神 経科学学会の会員.

\section{中 川大輝 (学生会員)}

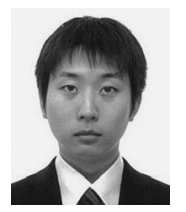

2013 年東北大学工学部情報知能システム総合学 科卒業. 同年同大学大学院情報科学研究科博士前 期 2 年の課程に進学. 現在に至る. 神経生理学の 研究に従事.

\section{上野 彩子}

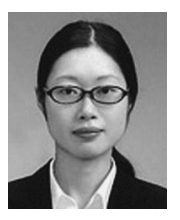

2010 年東北大学工学部電気情報 ・物理工学科卒 業. 2012 年, 同大学大学院情報科学研究科博士課 程前期 2 年の課程修了, 同年, 同大学院博士後期 3 年の課程に進学. 2013 年より日本学術振興会特別 研究員 (DC). 現在に至る. 神経の細胞外電気刺 激に関する研究に従事．日本神経科学学会, IEEE の会員.

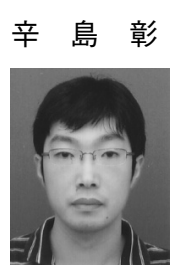

1999 年東北大学工学部情報工学科卒業, 2004 年同大学大学院情報科学研究科博士課程修了. 博 士 (情報科学). 同年より同大学院情報科学研究 科助手. 2007 年より同研究科助教となり, 現在に 至る. 生体情報学の研究に従事. 2003 年に日本睡 眠学会研究奨励賞を受賞. 北米神経科学学会, 日 本神経科学学会, 日本生理学会, 日本睡眠学会の 会員.

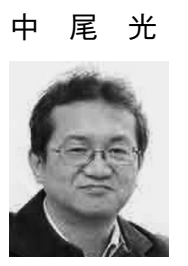

之（正会員）

1979 年山口大学工学部卒業. 84 年東北大学大 学院工学研究科博士課程修了. 工学博士. 東京都 老人総合研究所, 東北大学情報処理教育センター を経て， 88 年東北大学工学部助手. 91 年同助教 授. 93 年同大学院情報科学研究科助教授, 2003 年同教授となり，現在に至る。神経生理学，神経 回路網のモデル, 循環器系信号のモデル化, 生体 リズム機構のモデル化の研究に従事． IEEE，日本 生体医工学会, 日本神経科学学会, 日本生理学会, 日本睡眠学会, 電子情報通信学会の会員.

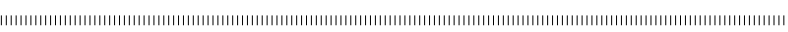

